\title{
A CREATIVE ALLIANCE BETWEEN LEARNER AUTONOMY AND ENGLISH LANGUAGE LEARNING: PAKISTANI UNIVERSITY TEACHERS’ BELIEFS
}

\author{
Musarat YASMIN $^{*}$, Ayesha SOHAIL ${ }^{2}$ \\ 1, 2 Department of English, Faculty of Arts, University of Azad Jammu and Kashmir, \\ Muzaffarabad, 13100, Pakistan \\ ${ }^{1}$ Department of English, Faculty of Arts, University of Gujrat, Gujrat, 50700, Pakistan
}

Received: 29 April 2017; accepted 15 November 2017

\begin{abstract}
Learner autonomy has been a focus of research for last three decades. Not only the nature of phenomenon was investigated but also its role in foreign language learning attracted researchers' interests. The present paper examines the mutual creative relationship between learner autonomy and target foreign language acquisition. Following an interpretive paradigm, this qualitative study used semi-structured interviews to explore the beliefs of 16 university teachers of English language teaching in four public sector universities of province Punjab, Pakistan. Results revealed a close creative connection between learner autonomy and English language learning. Teachers believed that autonomy in learners accelerates language learning. Major aspects of learner autonomy were reported fulfilling the perceived needs of foreign language learning. The study implied that fostering of autonomy in learners accelerates target language proficiency.
\end{abstract}

Keywords: English language learning (ELL), English teaching, language learner attributes, learner autonomy (LA), learner motivation.

\section{Introduction}

Learner autonomy (LA) has been a focus of growing research regarding its relation to foreign language learning over three decades (Benson, 2001; Little, 2009; Ushioda, 2011). Still, quite limited attention is being paid to an explicit LA autonomy with target language proficiency (Legenhausen, 2003; Apple, 2011; Dafei, 2007). Though learner's taking control of his learning process is not a new phenomenon, yet LA is well-established neither in perception nor in practices of Pakistani learners and teachers. The present study intends to explore Pakistani English teachers' beliefs about the significance of LA in English language learning (ELL) acquisition.

*Corresponding author. E-mail: musaratalvi@hotmail.com 


\section{Literature review}

Learner's central place in teaching has been well-established for last several decades. With a great deal of theorising, LA has attracted researchers over a period of more than three decades. LA, as defined by Henri Holec, is an "ability to take charge of one's own learning" where learner ability stands for having responsibility for all decisions related to one's learning including

"determining the objectives; defining the contents and progressions; selecting methods and techniques to be used; monitoring the procedure of acquisition properly speaking (rhythm, time, place, etc.); evaluating what has been acquired" (1981, p. 3).

Learner's willingness was also included stressing the fact that despite ability, learners would not be autonomous unless they want to (Dam, 1995). LA, hence, was theorised from a technical perspective involving learner skills to control to achieve goals, psychological perspectives involving learner characteristics as motivation, political perspective involving learner control over decisions and socio-cultural perspective involving learner ability to learn from knowledgeable others. An autonomous learner was considered a person with a set of attributes and skills (Benson, 2011) which may include but not restricted to self-awareness, curiosity, motivation, flexibility, confidence and persistence. An autonomous learner is independent of external help as well as interdependent (Candy, 1991).

Effective communication involves some skills which can be fostered only through use. Whereas a variety of these procedural skills are hard to be developed by in-class teaching (Hrochová, 2012), therefore, learners who are able or enabled to take charge of their learning, would be in a position to practice and master target language easily. LA and its contribution to ELL have been ignored by researchers (Little, 2007). Only a few quantitative studies supported the stance that LA accelerates ELL (Apple, 2011). The scarcity of research in this direction can be linked to multidimensional nature of both concepts: LA and ELL, as in case of LA, Terry Lamb (2010) explicated the difficulty to measure true ability to take charge.

Most of the studies conducted in present decade were quantitative (Apple, 2011; Sakai \& Takagi, 2009; Hashemian \& Soureshjani, 2011; Hrochová, 2012; Myartawan, Latief \& Suharmanto, 2013) except one which used mixed methods (Dafei, 2007). All these studies, conducted in China, Japan, and Indonesia, showed a strong positive relation between LA and ELL. A relationship between LA and English proficiency of 129 Chinese learners was examined by Deng Dafei (2007). Applying mixed methods, she used a standard language proficiency test, an autonomy measuring questionnaire and an interview to find causes of differences among learners. Results showed a significant and positive correlation between autonomy and language proficiency and led to a conclusion that fostering autonomy in language learners improves their language proficiency. A relationship between the two was again examined by Matthew Apple (2011) in 204 Japanese learners using quantitative questionnaires for both. The study showed a strong correlation between the two but researcher admitted the possible influence of other factors. Another quantitative comparative study conducted by Shien Sakai and Akiko Takagi (2009) examined the varying degree of autonomy in 721 Japanese learners of three different English proficiency. Survey results 
showed that learners with high score exhibited characteristics of independent language users, middle score holders were found independent learners while with low scores, learners were found more dependent. A relationship among autonomy, motivation and learner performance was analysed in Iranian second-language acquisition learners in the study of Mahmood Hashemian and Kamal Heidari Soureshjani (2011). It supported earlier findings with a positive significant relation between autonomy and language proficiency. Another study (Ünal, Çeliköz \& Sarı, 2017) gathered English language learners' perception of LA and its relationship with ELL proficiency. Their findings showed learners' positive perception about LA and learners' trust on a strong link between LA and language proficiency as they hold the belief that the more autonomous a learner will be, the more efficient language user he will be. Lenka Hrochová (2012) used a survey to find an opinion of 75 learners of a secondary school about the frequency of out-of-class activities, reasons of selecting particular activities, duration of time spent, learners' grade in English, type of activities they perceived effective and the type of language skills they felt complex. Learners involved in out-of-class activities were grouped as autonomous learners and results showed them achieving higher grades, taking language skills easier in comparison with other group. I Putu Ngurah Wage Myartawan, Mohammad Adnan Latief and Suharmanto (2013) followed similar research pattern and their survey of LA was compared with learners' grade point average. A comparison of both showed a strong correlation between the two. Learners with autonomy were those who benefited with language proficiency. Researchers also pointed to the need of focussing on innovation and creativity for better learner control and effective communication in ELL. Out of class activities using technology and social media were found supportive in autonomous learning (McLoughlin \& Lee, 2010). Phil Benson and Alice Chik (2010) supported the stance that evolving globalized online spaces opened new prospects for an autonomous language learning. Ali Abbas Falah Alzubi and Manjet Kaur Mehar Singh (2017) established that technology, particularly commonly used smartphones, enhanced autonomy in language learners as learners were found using learning strategies mediated by smart phone. Among these, social and metacognitive strategies were shown more common among learners. Few studies (Borg \& Busaidi, 2012; Shahsavari, 2014; Xhaferri, Waldispühl, Xhaferri \& Eriksson-Hotz, 2015; Salimi \& Ansari, 2015; Alzeebaree \& Yavuz, 2016) explored teachers' beliefs about LA and as the main focus was finding teachers' conceptual understanding, so contribution of LA in language learning was touched upon lightly and all of these studies showed teachers' positive beliefs about the relationship. It was established that LA allows a learner to learn language more effectively. Teachers are considered the agent of change and their understanding of the concept of LA and its practical link with language learning matters in classroom learning. Present study intended to bridge the methodological gap. Moreover, LA has been considered a new concept in the educational system in Pakistan as findings of the main study showed. English is an official language and despite present recent efforts to replace it with Urdu, still, English is used as the medium of instruction in education, the medium of governance in state affairs, the medium of communication in media, etc. (Yasmin, Sohail \& Mangrio, 2015; Yasmin, Sarkar \& Sohail, 2016). An exploratory study is the need of time to uncover Pakistani teachers' beliefs about LA and its link with ELL (Yasmin, Sohail, Sarkar \& Hafeez, 
2017). The present study would address this gap also through investigation the following research question.

1. What are teachers' beliefs about LA?

2. How far, in teachers' opinion, does LA contribute to ELL?

\section{Research design}

Following an interpretive paradigm, researchers conducted an exploratory qualitative study. A sample of sixteen English teachers (MI, IG, SH, SS, SB, SJ, RM, FM, AP, MA, KN, RJ, JJ, $\mathrm{SM}, \mathrm{ZK}, \mathrm{MN}$ ) was selected from regular faculty of English language teaching in four public universities in province Punjab: University of the Punjab, Government College University, University of Education and University of Gujrat. Single-gender and single-discipline institutes were excluded to get a homogenous sample. Data were collected through semi-structured interviews and questions were formed in the light of theoretical advancement found in the literature. Pseudonyms were used to keep the confidentiality of participants.

Data were analysed following the approach of constant comparison analysis. Multiple readings of the data led to the process of coding through breaking up the text (Hesse-Biber \& Leavy, 2006). Codes were reduced into manageable themes as was suggested by Carol A. Bailey (2007). Despite a list of themes informed by literature, coding process was kept open to explore the reality perceived through the lens of participants and researchers. Trustworthiness was intended to achieve following Yvonna Sessions Lincoln and Egon Guba (1985) through various ways. Interview transcripts were sent back to participants to verify truthfulness and results were interpreted with thick and rich verbatim description. The main study used triangulation to validate qualitative study.

\section{Results and discussions}

When participants were asked about their understanding of LA, a majority reported lack of familiarity or little recent acquaintance on a theoretical level only. They theorised LA as learner's ability to take charge of his learning independently and equated independence with absence of external help as one of them, RM, said, "they should be able to handle the situations where external help might not be available and they should be able to get through those difficult situations through their own resources" (source: interview data). However, it was also noted that participant teachers linked ability to act independently with learners' freedom with an emphasis on having "the power to direct himself [...] to detach himself from the bonds of typical educational environment" as another participant FM defined. The third element of LA was termed as learners' responsibility, whether solely or shared with the teacher. Moreover, they related LA with learners' curiosity and motivation to learn more. For them, an autonomous learner must be an explorer and intrinsically motivated as supported earlier by Michael P. Breen and Sarah J. Mann (2013). Also, an autonomous learner was defined as one who has a robust positive sense of self. It has been established that a poor self-concept of a learner affects learner activity (Stirin, Ganzach, Pazy \& Eden, 2012). 
The nature of the relationship between LA and foreign language learning was enquired to answer the second research question. Participants viewed LA as contributing factor in ELL and informed that it accelerates target language acquisition as one of them, RM, perceived an autonomous learner better able to set goals for learning and with positive learning habits may achieve language proficiency easily. Participants' emphasis on the degree of autonomy linked to learning a language recalls findings of previous researchers (Dafei, 2007; Apple, 2011; Hashemian \& Soureshjani, 2011; Hrochová, 2012; Myartawan et al. 2013) that the higher would be autonomy in learners, the more proficiency learners would achieve. Respondents related LA with ELL through highlighting a language learner's needs as illustrated in Table 1 which were considered essential characteristics of LA by theorists and researchers in the field.

Table 1. Transforming teaching practices to foster learner autonomy (Source: created by authors)

\begin{tabular}{|c|c|c|c|}
\hline No. & $\begin{array}{l}\text { Language Learning } \\
\text { requisites }\end{array}$ & Sub-Codes & Illustration \\
\hline \multirow[t]{3}{*}{1} & \multirow[t]{3}{*}{$\begin{array}{l}\text { Language learner } \\
\text { needs to take } \\
\text { charge of learning }\end{array}$} & $\begin{array}{l}\text { Language } \\
\text { learner should } \\
\text { devise his } \\
\text { own learning } \\
\text { mechanism }\end{array}$ & $\begin{array}{l}\text { "A learner devises different methods to bring himself } \\
\text { close to foreign language. He can use formal and } \\
\text { informal methods of learning". SB }\end{array}$ \\
\hline & & $\begin{array}{l}\text { Language } \\
\text { learner should } \\
\text { be goal- } \\
\text { oriented }\end{array}$ & $\begin{array}{l}\text { "In language learning also the students need to set } \\
\text { goals. For example, a student feels that he [...] does not } \\
\text { know the certain language structure, so he can actually } \\
\text { try to work on his structure". RM }\end{array}$ \\
\hline & & $\begin{array}{l}\text { Language } \\
\text { learner should } \\
\text { use multiple } \\
\text { resources }\end{array}$ & $\begin{array}{l}\text { "I come from a public sector school and I learnt most } \\
\text { of English from what I heard it on media and what I } \\
\text { heard from people speaking around me". MI }\end{array}$ \\
\hline 2 & $\begin{array}{l}\text { Language } \\
\text { learner needs to } \\
\text { experiment with/ } \\
\text { practice language }\end{array}$ & & $\begin{array}{l}\text { "The student has to be very experimental. First of all, } \\
\text { he should be open to new ideas, new words and new } \\
\text { techniques of learning". SM }\end{array}$ \\
\hline 3 & $\begin{array}{l}\text { Language learner } \\
\text { needs to be curious }\end{array}$ & & $\begin{array}{l}\text { "I want to learn English so whenever I come across new } \\
\text { words, I consult a dictionary. May be teacher didn't } \\
\text { want me to do that but because I wanted to learn so it } \\
\text { helped me that I wanted to shape my responses". RJ }\end{array}$ \\
\hline 4 & $\begin{array}{l}\text { Language learner } \\
\text { needs to be } \\
\text { motivated }\end{array}$ & & $\begin{array}{l}\text { "Once he enters into that new domain with a willing } \\
\text { mind than he has ability to exercise that autonomy with } \\
\text { full responsibility. It may speed up acquisition". SM }\end{array}$ \\
\hline 5 & $\begin{array}{l}\text { Language learner } \\
\text { needs confidence } \\
\text { building } \\
\text { environment }\end{array}$ & & $\begin{array}{l}\text { "If the learning environment is comfortable where the } \\
\text { learners feel encouraged, [...] and not afraid of asking } \\
\text { questions and seeking for help when necessary". SS }\end{array}$ \\
\hline
\end{tabular}


Participants viewed a close connection of both by relating LA to satisfying language learners' needs as one participant MI found ELL an area where autonomy could be more beneficial. They perceived that autonomous learners might become successful language users: language learners should understand the most appropriate methods of learning for him which may include, as SB found, books, workshops, seminars to understand target language culture; they should be able to organize learning and where ever they find deficiency in knowledge, they can work on it either independently or with peer help; they should be able to find multiple resources to learn target language, including teacher, peer, literature, media, journals, magazines, etc. Previous studies also showed that a variety of resources contribute to ELL or English-language learning. Use of literature was found exemplifying target language (Tasneen, 2010; Tehan, Yuksel \& Inan, 2015), while different forms of media were found optimum sources of English vocabulary and supportive in designing creative workshops (Lowe, 2007; Sweeting, 2009, 2010). On the other hand, identifying and seeking for a variety of resources was considered an essential ability of an autonomous learner (Little, 1991; Hedge, 2000). Success in ELL was related with interaction where principles of learner involvement, learner reflection and target language use are at work (Little, 2001). The very initial principle of learner involvement needs the teacher to bring learners into their own learning process, making them responsible for setting their learning goals, choosing learning materials and possible activities, handling interaction within the classroom and evaluating themselves. Hence autonomy sits comfortably with ELL.

Then, using these resources in practicing language leads to language proficiency as was shown by several studies (Schumann, 1978; Johnson \& Krug 1980). Participants perceived the sole aim of ELL to enable a learner to become autonomous user of language. One participant MA perceived the sole aim of ELL as to enable the learner to become an autonomous user of language. Another respondent SS called for a "comfortable" learning environment where the learner has the freedom to practice and experiment with language and freedom to ask for scaffolding if needed. Participant's perspective confirms arguments of David Little (2007) and Benson (2011) relating a high degree of LA with a high acquisition of target language.

Last three themes including learner curiosity, motivation and confidence refer to language learner attributes. Curiosity and motivation were reported significant in language learning by participants. Curiosity increases motivation in learners which in turn helps learners to fulfill their curiosity (Pluck \& Johnson, 2011). One participant RJ related it to LA which demands a curious mind and desire to learn on one's own. Research also showed that "autonomous learners are by definition motivated learners" (Ushioda, 1996, p. 2) and curious (Candy, 1991). Ema Ushioda's (1996) claim was later supported by Simon Borg and Saleh Al-Busaidi (2012).

\section{Conclusions}

The present study explored English teachers' beliefs about LA and its relationship with ELL. The results showed a strong link between LA and ELL. Participants believed that LA is contributing effectively in foreign language learning. They supported it through linking language learners' need with LA features. Thus, need to set goals, to plan a learning mechanism with 
a full understanding of one's weaknesses and strengths, to practice language through experimenting and identify learning material through various mediums are found matching successfully with salient characteristics and benefits of LA. Besides, features of an autonomous learner like curiosity, motivation and confidence are believed to make a language learner able to cope with ELL challenges. The study implies a critical role of teachers in providing learners with an autonomy supportive learning environment if target language proficiency is an aim. The study also recommends empirical classroom research to explore the relationship further.

\section{References}

Alzeebaree, Y., \& Yavuz, M. (2016). Learner autonomy: Iraqi EFL teachers' beliefs. European Scientific Journal, 12(31), 59-71. https://doi.org/10.19044/esj.2016.v12n31p59

Alzubi, A. A. F., \& Singh, M. K. M. (2017). The Use of language learning strategies through smartphones in improving learner autonomy in EFL reading among undergraduates in Saudi Arabia. International Journal of English Linguistics, 7(6), 59-72. https://doi.org/10.5539/ijel.v7n6p59

Apple, M. (2011). Autonomy as a predictor of English proficiency. OnCUE Journal, 4(3), 191-216.

Bailey, C. A. (2007). A guide to qualitative field research. Thousand Oaks, London, New Delhi: Pine Forge Press. https://doi.org/10.4135/9781412983204

Benson, P. (2001). Teaching and researching autonomy in language learning. Series: Applied linguistics in action. Ch. N. Candlin, D. R. Hall (General Eds.). Harlow: Pearson Education Limited.

Benson, P. (2011). Teaching and researching autonomy (2 ${ }^{\text {nd }}$ ed.). London and New York: Routledge.

Benson, P., \& Chik, A. (2010). New Literacies and Autonomy in foreign language learning. In M. J. Luzón, M. N. Ruiz-Madrid, M. L. Villanueva (Eds.), Digital genres, new literacies and autonomy in language learning (pp. 63-80). Newcastle upon Tyne: Cambridge Scholars Publishing.

Borg, S., \& Al-Busaidi, S. (2012). Teachers' beliefs and practices regarding learner autonomy. ELT Journal, 66(3), 283-292. https://doi.org/10.1093/elt/ccr065

Breen, M. P., \& Mann, S. J. (2013). Shooting arrows at the sun: Perspectives on a pedagogy for autonomy. In Ph. Benson, P. Voller (Eds.), Autonomy and independence in language learning (pp. 132-149). Series: Applied linguistics and language study. Ch. N. Candlin (General Ed.). London and New York: Routledge.

Candy, Ph. C. (1991). Self-direction for lifelong learning. San Francisco: Jossey-Bass.

Dafei, D. (2007). An exploration of the relationship between learner autonomy and English proficiency. Asian EFL Journal. Retrieved from http://www.asian-efl-journal.com/pta_Nov_07_dd.pdf

Dam, L. (1995). Learner autonomy: from theory to classroom practice (Vol. 3). Dublin: Authentik Language Learning Resources Ltd.

Hashemian, M., \& Soureshjani, K. H. (2011). The interrelationship of autonomy, motivation, and academic performance of Persian L2 learners in distance education contexts. Theory and Practice in Language Studies, 1(4), 319-326. https://doi.org/10.4304/tpls.1.4.319-326

Hedge, T. (2000). Teaching and learning in the language classroom. Series: Oxford Handbooks for Language Teachers. Oxford: Oxford University Press.

Hesse-Biber, S. N., \& Leavy, P. (2006). The practice of qualitative research. Thousand Oaks, London, New Delhi: SAGE Publications.

Holec, H. (1981). Autonomy and foreign language learning. Oxford/New York: Pergamon Press.

Hrochová, L. (2012). Relationship between learner autonomy and language proficiency. Thesis. University of West Bohemia. Plzeň. Retrieved from https://otik.uk.zcu.cz/bitstream/11025/5876/1/Diplomova\%20prace\%20-\%20Lenka\%20Hrochova.pdf 
Johnson, T. R., \& Krug, K. (1980). Integrative and instrumental motivations: in search of a measure. In J. W. Jr. Oller, K. Perkins (Eds.), Research in language testing (pp. 241-249). Rowley, Mass: Newbury House.

Lamb, T. (2010). Assessment of autonomy or assessment for autonomy? Evaluating learner autonomy for formative purposes. In A. Paran, L. Sercu (Eds.), Testing the untestable in language education (pp. 98-119). Series: New Perspectives on Language \& Education. Bristol, Buffalo, Toronto: Multilingual Matters.

Legenhausen, L. (2003). Second language acquisition in an autonomous learning environment. In D. Little, J. Ridley, E. Ushioda (Eds.), Learner autonomy in the foreign language classroom: teacher, learner, curriculum and assessment (pp. 65-77). Dublin: Authentik.

Lincoln, Y. S., \& Guba, E. G. (1985). Naturalistic inquiry. Newbury Park, London, New Delhi: SAGE Publications.

Little, D. (1991). Learner autonomy 1: definitions, issues and problems. Dublin: Authentik Language Learning Resources.

Little, D. (2001). We're all in it together: exploring the interdependence of teacher and learner autonomy. In L. Karlsson, F. Kjisik, J. Nordlund (Eds.), All together now: papers from the $7^{\text {th }}$ Nordic Conference and Workshop on Autonomous Language (pp. 45-56). Helsinki: Helsinki University, Language Center.

Little, D. (2007). Language learner autonomy: some fundamental considerations revisited. Innovation in Language Learning and Teaching, 1(1), 14-29. https://doi.org/10.2167/illt040.0

Little, D. (2009). Learner autonomy in action: adult immigrants learning English in Ireland. In F. Kjisik, P. Voller, N. Aoki, Y. Nakata (Eds.), Mapping the terrain of learner autonomy: Learning environments, learning communities and identities (pp. 51-85). Tampere: Tampere University Press.

Lowe, M. (2007). Films in English language teaching. IH Journal, 23, 16-19.

McLoughlin, C., \& Lee, M. J. W. (2010). Personalised and self regulated learning in the web 2.0 era: International exemplars of innovative pedagogy using social software. Australasian Journal of Educational Technology, 26(1), 28-43. https://doi.org/10.14742/ajet.1100

Myartawan, I. P., Latief, N. W., \& Suharmanto, M. A. (2013). The correlation between learner autonomy and English proficiency of Indonesian EFL college learners. TEFLIN Journal, 24(1), 63-81.

Pluck, G., \& Johnson, H. (2011). Stimulating Curiosity to Enhance Learning. GESJ: Education Science and Psychology 2(19): 24-31.

Sakai, Sh., \& Takagi, A. (2009). Relationship between learner autonomy and English language proficiency of Japanese learners. The Journal of Asia TEFL, 6(3), 297-325.

Salimi, A., \& Ansari, N. (2015). Learner autonomy: Investigating Iranian English teachers' beliefs. Theory and Practice in Language Studies, 5(5), 1106-1115. https://doi.org/10.17507/tpls.0505.28

Schumann, J. H. (1978). The Pidgination process: A model for second language acquisition. Rowley, Mass: Newbury House Publishers.

Shahsavari, S. (2014). Efficiency, feasibility and desirability of learner autonomy based on teachers' and learners' point of views. Theory and Practice in Language Studies, 4(2), 271-280. https://doi.org/10.4304/tpls.4.2.271-280

Stirin, K., Ganzach, Y., Pazy, A., \& Eden, D. (2012). The effect of perceived advantage and disadvantage on performance: The role of external efficacy. Applied Psychology, 61(1), 81-96. https://doi.org/10.1111/j.1464-0597.2011.00457.x

Sweeting, A. (2009). Language through Film. Sydney: Phoenix Education Pty.

Sweeting, A. (2010). Film-based activities to overcome the "gap-fill syndrome". English Australia Journal, 25(2), 51-57. 
Tasneen, W. (2010). Literary texts in the language classroom: A study of teachers' and students' views at international schools in Bangkok. Asian EFL Journal, 12(4), 173-187.

Tehan, P., Yuksel, D., \& Inan, B. (2015). The place of literature in an English language teaching program: What do students think about it?. The Reading Matrix: An International Online Journal, 15(2), 45-52.

Ünal, S., Çeliköz, N., \& Sarı, İ. (2017). EFL proficiency in language learning and learner autonomy perceptions of Turkish learners. Journal of Education and Practice, 8(11), 117-122.

Ushioda, E. (1996). Learner autonomy 5: The role of motivation. Dublin: Authentik: Language Learning Resources.

Ushioda, E. (2011). Why autonomy? Insights from motivation theory and research. Innovation in Language Learning and Teaching, 5(2), 221-232. https://doi.org/10.1080/17501229.2011.577536

Xhaferri, B., Waldispühl, M., Xhaferri, G., \& Eriksson-Hotz, B. (2015). Students' and teachers' beliefs about learner autonomy at SEEU Tetovo, Macedonia and PH Zug, Switzerland: A comparative study. In B. Xhaferri, M. Waldispühl, B. Eriksson-Hotz, G. Xhaferri (Eds.), Promoting learner autonomy in higher education (pp. 9-38). Tetovo: South East European University.

Yasmin, M., Sarkar, M., \& Sohail, A. (2016). Exploring English language needs in the hotel industry in Pakistan: An evaluation of existing teaching material. Journal of Hospitality \& Tourism Education, 28(4), 202-213. https://doi.org/10.1080/10963758.2016.1226846

Yasmin, M., Sohail, A., \& Mangrio, R. A. (2015). Myths broken or sustained: Representation of women victims in Pakistani media. Open Journal of Social Sciences, 3, 209-219. https://doi.org/10.4236/jss.2015.37033

Yasmin, M., Sohail, A., Sarkar, M., \& Hafeez, R. (2017). Creative methods in transforming education using human resources. Creativity Studies, 10(2), 145-158. https://doi.org/10.3846/23450479.2017.1365778

\title{
KÜRYBINĖ JUNGTIS TARP STUDENTO AUTONOMIJOS IR ANGLŲ KALBOS MOKYMOSI: PAKISTANO UNIVERSITETO DÉSTYTOJŲ NUOMONÉS
}

\author{
Musarat YASMIN, Ayesha SOHAIL
}

\begin{abstract}
Santrauka
Studento autonomijai dèmesys skiriamas tris pastaruosius dešimtmečius. Buvo ne tik nagrinėjamas reiškinio pobūdis, tyrejų interesus taip pat patraukè jo vaidmuo, mokantis užsienio kalbų. Šiame straipsnyje analizuojamas abipusis kūrybinis santykis tarp studento autonomijos ir ịvaldytos užsienio kalbos objekto. Remiantis interpretavimo paradigma, šiame kokybiniame tyrime naudojamasi pusiau struktūruotais interviu, siekiant išsiaiškinti 16-os anglų kalbos universiteto desstytojų nuomones keturiuose viešojo sektoriaus Pandžabo (Pakistanas) provincijos universitetuose. Rezultatai atskleidè glaudų kūrybinị ryšį tarp studento autonomijos ir anglų kalbos mokymosi. Dėstytojai buvo įsitikinę, kad studentų autonomija spartina kalbos mokymąsi. Buvo paskelbta, kad pagrindiniai studentų autonomijos aspektai atitiko pastebètus poreikius mokantis užsienio kalbos. Tyrimas atskleidè, kad studentų autonomijos skatinimas spartina pagrindinių kalbos įgūdžių ịgijimą.
\end{abstract}

Reikšminiai žodžiai: anglų kalbos mokymasis, anglų kalbos dèstymas, kalbos besimokančiojo savybès, studento autonomija, studento motyvacija. 